\title{
Research on Payment and Settlement Issues of Health, Safety and Environmental Provisions
}

\author{
Zhou Shuhan ${ }^{1}$ and Ke Hong ${ }^{2}$ \\ ${ }^{1,2}$ School of Management, Tianjin University of Technology, Tianjin, China \\ 1724884486@qq.com
}

Keywords: Health, safety and environmental provisions; Base;Rate; Adjustment; Payment

\begin{abstract}
With the continuous expansion of the construction scale, the problems of the safety of construction projects are being paid more and more attention by the professionals and relevant administrative departments. Health, safety and environmental provisions (costs for HSE ) as a non competitive costs, so it must be full charged, timely paid, earmark payment professional use. The study about the research on costs for HSE is rare. Therefore, through literature research and combination with the provision costs for HSE based on code of bills of quantities and valuation for construction works(13 list), this paper from the two angles of the tenderer and the bidder to determine the tendering phase of the costs for HSE, according to "items" measurement and "quantity" measurement two ways to analyze the costs for HSE adjustment method, finally ascertain the amount of the payment of the costs for HSE, strengthen the 13 list in the practical application operability.
\end{abstract}

\section{Introduction}

At present, in our country's engineering construction practice, the phenomenon that the cost for HSE is neglected and the hidden danger of construction accidents is increased, and the safety management of construction industry has gradually become the focus of social attention. In this regard, the government departments are constantly working to improve the safety of production laws, regulations and rules, and regulate the construction of trading activities, increase the intensity of production safety supervision. Cost for HSE is an important and indispensable cost to ensure the construction safety and civilization. Variation order, discrepancy in BQ quantity and technical standards change, may affect one or several measures of safe and civilized construction, resulting in costs for HSE valuation base change, the adjustment is reasonable or not directly affect the smooth progress of the construction project. Therefore, it is necessary to make a research on payment and settlement issues of cost for HSE, which is to protect the interests of both parties.

In the field of project management research, the research on costs for HSE is mainly reflected in strengthening the safe and civilized construction management measures ${ }^{[1,2]}$, safe and civilized construction management problems and the current situation ${ }^{[3,4]}$, calculation of the costs for $\operatorname{HSE}^{[5,6]}$, and adjustment issues of costs for $\mathrm{HSE}^{[7,8]}$ and so on. At present, the relevant scholars are mainly focus on construction management measures and current problems, research on payment and settlement issues of costs for HSE is relatively small. Therefore, this paper discuss the payment and settlement issues of costs for HSE according to the contract price adjustment provisions from the 13 list, to provide strong support for the successful resolution of the focus of both parties.

\section{The determination of costs for HSE in the tendering phase}

The determination of costs for HSE in the tender sum limit. When the tenderer and the agency in preparation of tender documents or tender sum limit, should set costs for HSE separately. 
44 article provisions"... three calculation base of costs for HSE: base price of norm (expenses of divisional and elemental works + expenses of preliminaries which can measure), labor cost, and labor cost + machinery operation or rental fee ...". Various provinces take the different standards of costs for HSE, the calculation base and rates vary from province to province. In this paper, through the research of the costs for HSE in various provinces and cities in China, the base and the rates are summarized as shown in table 1.

Table 1 The calculation base and rates of costs for HSE in different provinces

\begin{tabular}{|c|c|l|l|}
\hline $\begin{array}{c}\text { Serial } \\
\text { number }\end{array}$ & Region & \multicolumn{1}{|c|}{ Calculation base } & Rates (\%) \\
\hline 1 & east & expenses of divisional and elemental works & 2.87 \\
\hline 2 & south & expenses of divisional and elemental works & 3.84 \\
\hline 3 & central & labor cost + machinery operation or rental fee & 15.3 \\
\hline 4 & north & $\begin{array}{l}\text { expenses of divisional and elemental works }+ \\
\text { expenses of preliminaries which can measure }\end{array}$ & 4.7 \\
\hline 5 & northwest & $\begin{array}{l}\text { expenses of divisional and elemental works( labor } \\
\text { cost }+ \text { machinery operation or rental fee) } \\
\text { expenses of preliminaries which can measure } \\
\text { (labor cost + machinery operation or rental fee) }\end{array}$ & 6.21 \\
\hline 6 & southwest & $\begin{array}{l}\text { expenses of divisional and elemental works( labor } \\
\text { cost })+ \text { expenses of preliminaries which can } \\
\text { measure ( labor cost ) }\end{array}$ & 11.1 \\
\hline 7 & northeast & $\begin{array}{l}\text { (labor cost + machinery operation or rental fee)/ } \\
\text { expenses of divisional and elemental works }+ \\
\text { expenses of preliminaries +sundry costs }\end{array}$ & $9.06 / 1.32$ \\
\hline
\end{tabular}

The tenderer according to table 1. select a costs for HSE calculation base, if base price of norm for calculation base, the tenderer should calculate quantities of divisional and elemental works and preliminaries which can measure, is to work out preliminaries, work sections and BQ ( bills of quantities for tendering ), then multiplied by all-in unit rate to determine the calculation base, finally according to the corresponding rate of determination by project cost management agencies, multiplied by the base to determine costs for HSE. If labor cost, or labor cost + machinery operation or rental fee for calculation base, the tenderer should according to the area of construction project estimate base of norm is given in labor and machinery operation or rental fee costs to determine, and then labor cost or machinery operation or rental fee is multiplied by the corresponding quantities, the results multiplied by the corresponding rates are costs for HSE.

The determination of costs for HSE in the tendering sum. (1) The tender documents stipulate tendering sum of costs for HSE ought to transcribe directly, for example, the tender documents stipulate: " tendering sum of costs for HSE is 500000 yuan". This shows that the costs for HSE is fixed, each bidder must be in accordance with the provisions of the tender documents, the amount of costs for HSE, which is in line with the characteristics of costs for HSE as a non competitive costs.

(2) The tender documents stipulate according to area stipulation calculate costs for HSE, has defined the calculation base and rates of costs for HSE. Bills of quantities for tendering already 
listed the bidder should follow the areas specified in the tender documents to take into account the base of costs for HSE were in full accrual. At this time the bidder in the preparation of costs for HSE in the tendering sum, should not change the base and according to bills of quantities for tendering, which has already given.

\section{Adjustment of costs for HSE}

The adjustment method of costs for HSE according to "items" measurement. (1) The adjustment caused by costs for HSE base change. The adjustment of costs for HSE caused by discrepancy in BQ quantity, missing item, variation order, change in laws and regulations is related to the calculation base and rates of costs for HSE, if calculation base and rates are determined, cost adjustment amount can be obtained.

Table2 The adjustment caused by costs for HSE base change

\begin{tabular}{|c|c|c|}
\hline $\begin{array}{l}\text { Calculation } \\
\text { base }\end{array}$ & $\begin{array}{l}\text { Reason for } \\
\text { adjustment }\end{array}$ & Adjustment method \\
\hline \multirow{4}{*}{$\begin{array}{l}\text { base price } \\
\text { of norm }\end{array}$} & $\begin{array}{c}\text { discrepancy } \\
\text { in BQ } \\
\text { quantity }\end{array}$ & $\begin{array}{l}\text { adjustment amount of costs for HSE }=\text { discrepancy } \\
\text { quantity } \times \text { estimate price } \times \text { rate }\end{array}$ \\
\hline & $\begin{array}{l}\text { missing } \\
\text { item }\end{array}$ & $\begin{array}{l}\text { adjustment amount of costs for HSE }=\text { new item quantity } \\
\qquad \times \text { estimate price } \times \text { rate }\end{array}$ \\
\hline & $\begin{array}{l}\text { variation } \\
\text { order }\end{array}$ & $\begin{array}{l}\text { variation order cause the original project quantity increase } \\
\text { or decrease can be adjusted according to the adjustment } \\
\text { method of discrepancy in BQ quantity; variation order } \\
\text { cause new projects or to cancel the project can be adjusted } \\
\text { according to adjusting method of missing item }\end{array}$ \\
\hline & $\begin{array}{l}\text { change in } \\
\text { laws and } \\
\text { regulations }\end{array}$ & $\begin{array}{l}\text { adjustment amount of costs for } \mathrm{HSE}=(\text { estimate price }- \\
\text { original }) \times \text { quantity } \times \text { rate }\end{array}$ \\
\hline \multirow{4}{*}{$\begin{array}{c}\text { labor cost, } \\
\text { or labor } \\
\text { cost }+ \\
\text { machinery } \\
\text { operation } \\
\text { or rental } \\
\text { fee }\end{array}$} & $\begin{array}{c}\text { discrepancy } \\
\text { in } \mathrm{BQ} \\
\text { quantity }\end{array}$ & $\begin{array}{c}\text { adjustment amount of costs for } \mathrm{HSE}=(\text { labor cost- } \\
\text { original labor cost }) \times \text { rate }\end{array}$ \\
\hline & $\begin{array}{l}\text { missing } \\
\text { item }\end{array}$ & $\begin{array}{l}\text { adjustment amount of costs for } \mathrm{HSE}=(\text { missing item } \\
\text { labor cost } / \text { original labor cost }) \times \text { original costs for HSE }\end{array}$ \\
\hline & $\begin{array}{l}\text { variation } \\
\text { order }\end{array}$ & $\begin{array}{l}\text { adjustment amount of costs for } \mathrm{HSE}=(\text { labor cost } / \\
\text { original labor cost }) \times \text { original costs for HSE }\end{array}$ \\
\hline & $\begin{array}{l}\text { change in } \\
\text { laws and } \\
\text { regulations }\end{array}$ & $\begin{array}{l}\text { adjustment amount of costs for HSE }=(\text { labor cost- } \\
\text { original labor cost }) \times \text { quantity } \times \text { rate }\end{array}$ \\
\hline
\end{tabular}

(2) The adjustment caused by costs for HSE rate change. The adjustment caused by change in laws and regulations is costs for HSE according to "items" measurement. The adjustment method: 
adjustment amount of costs for HSE $=$ calculation base $\times($ rate - original rate $)$, the adjusted rate can refer to the relevant state departments issued by the relevant departments to determine.

The adjustment method of costs for HSE according to " quantity " measurement. (1) Discrepancy in BQ quantity. 13 list prescribe for any bills of quantities for tendering project, if the actual quantities which should be measured and bills of quantities for tendering appeared deviation, and discrepancy in BQ quantity caused by variation order, when the deviation exceeds $15 \%$, increase quantities of more than $15 \%$ of the corresponding all-in unit rate lowered; reduce the amount of the remaining part of the project, the corresponding all-in unit rate should raise..

(2) Variation order. The adjustment of variation order and discrepancy in BQ quantity, 13 list prescribe: “...safe and civilized construction measures change caused by variation order and discrepancy in BQ quantity cause construction plan change, the contractor proposed adjustment should be prior to the proposed implementation plan submitted to the employer to confirm, after contracting parties to confirm execution... ". The adjustment method: adjustment amount of costs for $\mathrm{HSE}=$ costs for HSE - original costs for HSE.

(3) Missing item. Adjustment method of division and elemental works missing item in the bills of quantities for tendering: safe and civilized construction measures change caused by site enclosure, site hard and temporary buildings according to "quantity" measurement, the contractor will develop the construction plan submitted to the employer confirm, calculated according to the actual quantity, price according to the variation order evaluation three principles and preliminaries adjustment principle to adjust; Adjustment method of costs for HSE which can be measured missing item in the bills of quantities for tendering: preliminaries missing caused by site enclosure, site hard and temporary buildings according to "quantity" measurement, the contractor will develop the construction plan submitted to the employer confirm, according to the variation order evaluation three principles to adjust costs for HSE.

\section{Payment of costs for HSE}

Payment methods of costs for HSE. 13 list 10.2.2 prescribe the employer shall be paid not less than $60 \%$ of the total costs for HSE of construction schedule within 28 days after the start of the project, the rest should be decomposed according to the principles of the arrangements in advance, and with the progress payment over the same period to pay. This paper will analyze and define the rest of the payment methods of costs for HSE.

(1) Temporary facilities fee adopt ratio method. Temporary facilities fee includes construction site temporary buildings, structures, erection of temporary facilities, maintenance, removal or amortization costs[9], this category of costs using the ratio method. As the temporary facilities fee is a one-time cost of investment, so the contract can be agreed in the proportion of temporary facilities fee payment. If the duration is less than 2 months, you can use the $0 / 100 \%$ method, as a result of a short period of time, at the beginning of the project does not pay the price, pay the full cost after completion; if the duration is longer in 3-6 months of the project, you can pay a larger proportion at beginning, $30 \% / 70 \%$ refers to at beginning of the project activities, pay $30 \%$ of the contract price and the rest in the completion of the settlement payment; and for a period longer than 6 months of the project, the temporary facilities fee payment method can be 50\%/50\%.

(2) Environmental protection fee, civilized construction costs, safe construction costs can adopt the percentage of completion method and schedule progress percentage method. Using the percentage of completion method, according to the completion of the expenses of divisional and elemental works for a percentage of the total expenses of divisional and elemental works, multiplied by the environmental protection fee, civilized construction costs, safe construction costs, you can 
calculate this month to pay for environmental protection fee, civilized construction, safe construction costs. You can also use the schedule progress percentage method, this method is based on a percentage of the project has progressed to the total duration of the period and then multiplied by environmental protection fee, civilized construction costs, safe construction costs, calculated progression to this period costs should be paid. Calculation should subtract the duration of the progress delay caused by the contractor, because this period is due to the contractor, result in quantities did not reach the corresponding workload, so should not be pay the price.

Payment progress of costs for HSE. (1) Advance payment of costs for HSE. The employer shall be paid not less than $60 \%$ of the total costs for HSE of construction schedule within 28 days after the start of the project, the rest should be paid according to the progress payment. Costs for HSE is necessary to protect the construction site safe and orderly conduct, and as a non competitive costs, the employer should be strictly in accordance with the contract in good time and proportion on time and in full prepaid costs for HSE to the contractor.

(2) Progress payment of costs for HSE. The remaining part of the costs for HSE should be decomposed according to the principles of the arrangements in advance, and with the progress payment over the same period to pay. Contract should be clearly defined the payment method of costs for HSE progress payment, according to the agreed payment method, work out this period shall be paid for the costs for HSE in the progress payment. The contractor shall according to the provisions of schedule disbursement costs for HSE, the employer after the confirmation to pay.

(3) Settlement payment of costs for HSE. A series of design changes and site instruction, as well as changes in the pricing policies and regulations of the national and regional measures directly to the project settlement. The contractor shall carefully and timely in accordance with the terms of the settlement, finishing complete settlement data and auxiliary data to ensure the costs for HSE settlement is consistent with the actual situation[10]. The project cost management agencies can also carry out the state-owned investment project completion settlement filing system, review and supervision of costs for HSE in settlement calculation. After completion of the audit settlement payment, paid costs for HSE settlement price.

\section{Conclusion}

This paper research on payment and settlement issues of health, safety and environmental provisions based on code of bills of quantities and valuation for construction works (GB50500-2013), through literature research and studies on the various provinces and cities costs for HSE regulations, according to costs for HSE payment of the entire process, from plan to take, adjustment and payment three aspects to analyze costs for HSE. This paper summarizes the calculation base and rates of costs for HSE in different provinces, work out the specific adjustment method of discrepancy in BQ quantity, missing item, variation order, change in laws and regulations according to "items" measurement and "quantity" measurement. Advance payment, progress payment and settlement payment of costs for HSE were summarized according to 13 list, to draw the payment situation in various stages. The research on payment and settlement issues of health, safety and environmental provisions provide a good basis for both contract parties, and provides a solid foundation for the healthy development of engineering practice.

\section{References}

[1] Guan Hui. Discuss on Management of Costs of Safety and Civilized Construction [J]. Fujian Architecture, 2011(11):81-83. 
[2] Zhang Qianchuan. Discuss on Management Measures of Construction Safety Civilization Construction [J]. Sichuan Cement, 2014(12):184-185.

[3] Zhuo Jianguo. Discuss on Construction Safety Civilization Construction Management [J]. Architecture and Decoration, 2008(5):431-432.

[4] Yan Min, Wang Fei, Yan Ling. Research on Adjustment of costs for HSE under Bills of Quantities for Tendering Valuation [J]. Construction Economy, 2014(8): 56-59.

[5] Liang Chenqing. Analysis of Calculate Construction Engineering Costs for HSE. [J]. Construction Economy, 2009(S1):325-328.

[6] Qi Haixia. Discuss on Construction Engineering Costs for HSE. [J]. Henan Science and Technology, 2014(14):190.

[7] Xu Bing, Wang Shaoxing, Zhu Hailong. A Study on Valuation and Adjustment of Safety Civilized Construction Costs. [J]. Shanxi Architecture, 2014,40(36): 232-234.

[8] Yan Ling, Zhao Chaochao. Expenses of Preliminaries Adjust Based on Quantities Change. [J]. Construction Economy, 2013(9):46-50.

[9] Liu Yulan. Discuss on Bills of Quantities for Tendering Missing Item Handing Issues. [J]. Guide of Science and Technology, 2010(6):275-276.

[10]Gong Lei. Application Analysis of Costs for HSE Management of Construction Unit [J]. Shanghai Power, 2011(5):394-397. 